\title{
A study on relationship between audit quality and earnings management in Iranian banking industry
}

\author{
Mohammad Masihi*
}

M.Sc. of Accounting, Department of Accounting, Tehran Central Branch, Islamic Azad University (IAU), Tehran, Iran

\section{H R O N I C L E}

Article history:

Received May 16, 2013

Received in revised format

12 September 2013

Accepted 26 October 2013

Available online

October 282013

\section{Keywords:}

Earnings management

Audit quality

Banking industry

\section{A B S T R A C T}

\begin{abstract}
This paper presents an empirical investigation to study the relationship between audit quality and earnings management in Iranian banking industry. The proposed study gathers the necessary information from 18 different Iranian banks over the period 2005-2012. The study considers the effects of three independent variables including type of auditing, tenure of auditing and size of bank on earning managements. The result of our survey has indicated that there was a meaningful and reverse relationship between type of accounting and earnings management. In addition, the longer an auditing firm perform auditing program, the better the firm reports earnings management. Finally, as the size of firm increases, there is a better earnings management.
\end{abstract}

\section{Introduction}

Earnings management plays essential role on making wise investment decisions. An appropriate technique for forecasting stock price may always create good investment opportunities (Schipper \& Vincent, 2003; Balsam et al., 2003; Bae \& Sami, 2005; Abednazari \& Noravesh, 2013). There are literally different studies on learning more about earnings management. Maranjory et al. (2013) studied the role of discretionary accruals in the earnings management of some Iranian firms. Hayatbakhsh and Esmaeilzade Maghariee (2013) performed a study on relationship between asymmetric information on dividend polices of some TSE companies. Dadbeh and Mogharebi (2013) investigated the impact of information asymmetry on earning management (Zhang, 2009) by examining a sample of 47 TSE companies over the period 2002-2008 based on panel data. They reported that the information asymmetry maintained some meaningful effects on earnings management.

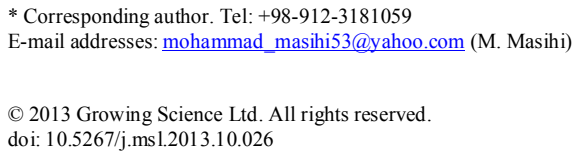


Ahmadi et al. (2013) presented a logistic regression model to compute risk management of receivable accounts on some selected firms from drug industry listed on TSE. They studied the effects of different variables such as current ratio, quick ratio, working capital on total assets and cash flow on economic value added by collecting the necessary information of 29 firms over the period 2006-2011 and reported that the proposed model was capable of forecasting high profit firms with good probability. Khaksarian (2013) studied the relationship between earnings response coefficient and earnings management on some selected firms listed in Tehran Stock Exchange (TSE).

Banimahd and Jalali Aliabadi (2013) studied the relationship between earnings management and operating cash flows management on some selected TSE firms. They reported that there was a meaningful relationship between earnings management and operating cash flows management. Ghodrati et al. (2013) evaluated the impact of profit quality structures on capital cost and the primary objective was to disclose the impact to investors. They reported that the estimated model could explain 22 percentages of variable changes. This means that there was a weak linear relationship between cost of capital and profit persistence, profit predictability and other variables. Based on the regression estimation they reported that there was a direct relationship between earnings persistence and cost of capital and there was a reverse relationship between earnings predictability and cost of capital.

Emamgholipour et al. (2013) investigated the relationship between institutional investors and earnings management on some listed companies on Tehran Stock Exchange by testing a sample of 700 firm-years data over the period 2006-2010. In this study, the discretionary accruals were implemented as an indicator for earnings management. They reported that there was a positive and significant relationship between institutional investors and earnings management and recommended that increasing the ownership percentage of institutional shareholders could increase earnings management. In addition, the results of the control variables indicated that firm size had no impact on earnings management, but financial leverage and return on sales, respectively had negative and positive effect on the earnings management of companies. Yoon and Miller (2002) investigated the effects of cash from operations and earnings management in Korea. Nikoomaram et al. (2012) performed an empirical analysis of earnings management motives in firms listed on Tehran Stock Exchange. Miranda-Lopez and Nichols (2012) provided some experimental evidence on the use of earnings and cash flows in investment decisions in the US and Mexico.

\section{The proposed model}

The proposed model of this paper uses Jones' revised model to measure earnings management as follows,

$T A C_{i t} / T A_{i t-1}=a_{0}\left(1 / T A_{i t-1}\right)+a_{1 j}\left(\Delta R E V_{i t}-\Delta R E C_{i t}\right) / T A_{i t-1}+a_{2 j}\left(P P E_{i t} / T A_{i t-1}\right)+e_{i b}$

where $T A C_{i}$ represents total accrual, $T A_{i t-1}$ is total assets for firm $i$ in year $t-1, D R E V_{i t}$ is the change in revenue from $t$ to $t-1, D R E C_{i t}$ is the change in receivable accounts from $t$ to $t-1, P P E_{i t}$ is the growth value of equipment for year $t$, and $e_{i t}$ represents residuals. In addition, the managed components of total accruals $(T A E M)$ is calculated as follows,

$T A E M_{i t}=T A C_{i t} / T A_{i t-1}-a_{0 j}\left(1 / T A_{i t-1}\right)-a_{l j}\left(\Delta R E V_{i t}-\Delta R E C_{i t}\right) / T A_{i t-1}-a_{2 j}\left(P P E_{i t} / T A_{i t-1}\right)$.

There are two main hypotheses associated with the proposed study of this paper as follows,

1. There is a relationship between type of auditing and earnings management.

2. There is a relationship between auditing tenure and earnings management. 
There is also one sub hypothesis associated with the proposed study of this paper as follows,

3. There is a relationship between bank size and earnings management.

The proposed study gathers the necessary information from 18 different banks over the period 20052012. We first present details of our findings based on some basic statistics summarized in Table 1 as follows,

\section{Table 1}

The summary of some basic statistics

\begin{tabular}{|c|c|c|c|c|c|c|c|}
\hline \multirow{2}{*}{ Variable } & \multirow{2}{*}{ Mean } & \multirow{2}{*}{ Median } & \multirow{2}{*}{$\begin{array}{l}\text { Standard } \\
\text { deviation }\end{array}$} & \multirow{2}{*}{ Skewness } & \multirow{2}{*}{ Kurtoses } & \multicolumn{2}{|c|}{ Jarku-Bra } \\
\hline & & & & & & Statistics & Sig. \\
\hline Total accruals & -0.0340 & -0.02 & 0.2622 & -10.635 & 234.93 & 20139 & 0.0000 \\
\hline Change in revenue and receivable accounts & -0.5607 & 0.0300 & 4.7687 & -10.976 & 149.23 & 820942 & 0 \\
\hline Growth net of equipment & 0.2611 & 0.2200 & 0.1860 & 0.9918 & 3.6094 & 161.67 & 0.0000 \\
\hline
\end{tabular}

In addition, we have measured the Pearson correlation ratio between change in revenue and receivable accounts on one side and growth net of equipment on the other side and the results was equal to 0.9192 where the level of significance is equal to 0.003384 . Next we use Chow Test to understand whether we should choose no effect or with effect and Hausman Test to find out whether we should choose Fixed Effects or Random Effects. Table 2 demonstrates the results of our survey.

Table 2

The summary of Chow and Hausman tests

\begin{tabular}{ccccc}
\hline test & Statistics & Value & df & Sig. \\
\hline Chow & $\mathrm{F}$ & 1.2344 & $(153.733)$ & 0.0409 \\
Hausman & $\mathrm{H}$ & 4.1864 & 2 & 0.1233 \\
\hline
\end{tabular}

According to the results of Table 2, we can use fixed effect method for the regression analysis. Next, we present details of our findings.

\section{The results}

In this section, we present details of our findings on applying regression technique. We first present total accrual estimation in Eq. (3) as follows,

\begin{tabular}{|c|c|c|c|}
\hline \multirow{3}{*}{$\begin{array}{r}\text { ACC } \\
\text { Standard deviation }\end{array}$} & \multirow{2}{*}{$=0.017617$} & \multicolumn{2}{|r|}{$-0.197470 \times \mathrm{PPE}+\varepsilon$} \\
\hline & & $(0.000341)$ & $(0.027125)$ \\
\hline & 2.369665 & 1.979701 & -7.280091 \\
\hline Sig. & 0.0181 & 0.0481 & 0.0000 \\
\hline F-value $=2.946992$ & $(0.000)$ & Adjusted-R-Square $=0.263616$ & Durbin-Watson $=2.178376$ \\
\hline
\end{tabular}

As we can observe from the results of regression analysis, all coefficients of independent variables are statistically significance with $\alpha=5 \%$. In addition, Durbin-Watson is equal to 2.17 , which is within an acceptable limit. Now, we present details of our findings on relationship between earnings management (EM) and three independent variables including auditing type, auditing tenure and bank size. 


\begin{tabular}{|c|c|c|c|c|}
\hline Standard dev. & $(0.009526)$ & $(0.043996)$ & $(0.0096409)$ & $(0.054)$ \\
\hline t-value & 8.487266 & -2.043416 & 3.101577 & 16.441 \\
\hline Sig. & 0.0000 & 0.0443 & 0.0035 & 0.0000 \\
\hline
\end{tabular}

F-value $=5.32(0.000) \quad$ Adjusted-R-Square $=0.52 \quad$ Durbin-Watson $=1.81$

According to the results of regression analysis stated in Eq. (4), all coefficients are meaningful when the level of significance is five percent. Durbin-Watson is equal to 1.81 , which means there is no auto-correlation among independent variables.

\subsection{The first hypothesis: The relationship between earnings management and auditing type}

The first hypothesis of the survey investigates whether there is any relationship between earnings management and auditing type. Based on the results of Eq. (4) we have,

$$
\left\{\begin{array} { l } 
{ H _ { 0 } : \beta _ { D A , A U T Y P E } = 0 } \\
{ H _ { 1 } : \beta _ { D A , A U T Y P E } \neq 0 }
\end{array} \Rightarrow \left\{\beta=-0.089, \quad T=-2.04, t_{o b}>\left|t_{c}\right|,-2.04>|1.96,2.58|, p=0.0443\right.\right.
$$

Therefore, we can confirm the first hypothesis of this survey and claim that there is indeed a negative relationship between auditing type and earnings management.

\subsection{The second hypothesis: The relationship between earnings management and auditing tenure}

The second hypothesis of the survey investigates whether there is any relationship between earnings management and auditing tenure. Based on the results of Eq. (4) we have,

$$
\left\{\begin{array} { l } 
{ H _ { 0 } : \beta _ { D A , \mathrm { AU } - \mathrm { TEN } } = 0 } \\
{ H _ { 1 } : \beta _ { D A , \mathrm { AU } - \mathrm { TEN } } \neq 0 }
\end{array} \Rightarrow \left\{\beta=0.02990 \quad T=3.10, t_{o b}>\left|t_{c}\right|, 3.10>|1.96,2.58|, p=0.0035\right.\right.
$$

Therefore, we can confirm the second hypothesis of this survey and claim that there is indeed a positive relationship between auditing tenure and earnings management.

\subsection{The third hypothesis: The relationship between earnings management and bank size}

The third hypothesis of the survey investigates whether there is any relationship between earnings management and bank size. Based on the results of Eq. (4) we have,

$$
\left\{\begin{array} { l } 
{ H _ { 0 } : \beta _ { E M , \text { BankSize } } = 0 } \\
{ H _ { 1 } : \beta _ { E M , \text { BankSize } } \neq 0 }
\end{array} \Rightarrow \left\{\beta=0.881 \quad T=16.441, t_{o b}>\left|t_{c}\right|, 16.441>|1.96,2.58|, p=0.0000\right.\right.
$$

Therefore, we can confirm the third hypothesis of this survey and claim that there is indeed a positive relationship between bank size and earnings management.

\section{Conclusion}

In this paper, we have presented an empirical investigation to study the effects of auditing type, auditing tenure and bank size on earnings management. The proposed study of this paper selected 8year data from banking sector over the period 2005-2012 and using regression analysis, the study confirmed the effects of auditing type, auditing tenure and bank size on earnings management. In 
other words, the result of our survey has indicated that there was a meaningful and reverse relationship between type of accounting and earnings management. In addition, the longer an auditing firm perform auditing program, the better the firm reports earnings management. Finally, as the size of firm increases, there is a better earnings management.

\section{Acknowledgment}

The authors would like to thank the anonymous referees for constructive comments on earlier version of this paper.

\section{References}

Abednazari, M., \& Noravesh, I. (2013). A study on relationship between investment opportunities and earnings: A corporate life cycle investigation. Management Science Letters, 3(7), 2039-2048.

Ahmadi, M., Pouraghajan, A.A., \& Salehnezhad, S.H. (2013). Performance measurement of receivable accounts' risk management: A case study of Tehran Stock Exchange. Management Science Letters, 3(6), 1593-1598.

Bae, B., \& Sami, H. (2005). The effect of potential environmental liabilities on earnings response coefficients. Journal of Accounting, Auditing \& Finance, 20(1), 43-70.

Banimahd, B., \& Jalali Aliabadi, M. (2013). A study on relationship between earnings management and operating cash flows management: Evidence from Tehran Stock Exchange. Management Science Letters, 3(6), 1677-1688.

Balsam, S., Krishnan, J., \& Yang, J. S. (2003). Auditor industry specialization and earnings quality. Auditing: A Journal of Practice \& Theory, 22(2), 71-97.

Dadbeh, F., \& Mogharebi, N. (2013). A study on effect of information asymmetry on earning management: Evidence from Tehran Stock Exchange. Management Science Letters, 3(7), 2161 2166.

Emamgholipour, M., Babanejad Bagheri, S.M., Mansourinia, E., \& Arabi, M. (2013). A study on relationship between institutional investors and earnings management: Evidence from the Tehran Stock Exchange. Management Science Letters, 3, 1105-1112.

Ghodrati, H., Ghazi Fini, S.R., \& Kashaninezhad Abyaneh, M. (2013). An investigation on the effects of the profit quality structures on Iranian firms' capital cost. Management Science Letters, 3(6), $1719-1724$.

Hayatbakhsh, A., \& Esmaeilzade Maghariee, A. (2013). A study on relationship between asymmetric information on dividend polices of companies listed in Tehran Stock Exchange. Management Science Letters, 3(7), 2089-2094.

Jones, J. J. (1991). Earnings management during import relief investigations. Journal of accounting research, 29(2), 193-228.

Khaksarian, F. (2013). A study on relationship between earnings response coefficient and earnings management: Evidence from Tehran Stock Exchange. Management Science Letters, 3(10), 25492554.

Maranjory, M., Alikhani, R., Zabihzadeh, A., \& Sepehri, P. (2013). The role of discretionary accruals in earnings management: Evidence from Tehran Stock Exchange. Management Science Letters, 3(9), 2399-2404.

Miranda-Lopez, J. E., \& Nichols, L. M. (2012). The use of earnings and cash flows in investment decisions in the US and Mexico: Experimental evidence. Journal of International Accounting, Auditing and Taxation, 21, 198-208.

Nikoomaram, H., Banimahd, B., \& Shokri, A. (2012). An empirical analysis of earnings management motives in firms listed on Tehran Stock Exchange. Journal of Basic and Applied Scientific Research 2(10), 9990-9993. 
Ohlson, J. A. (1995). Earnings, book values, and dividends in equity valuation. Contemporary accounting research, 11(2), 661-687.

Schipper, K., \& Vincent, L. (2003). Earnings Quality. Accounting Horizons, 17, 97-110.

Yoon, S. S., \& Miller, G. A. (2002). Cash from operations and earnings management in Korea. The International Journal of Accounting, 37(4), 395-412.

Zhang, R. (2009). Cash flow management in the Chinese stock market: An empirical assessment with comparison to the US Market. Frontiers of Business Research in China, 3(2), 301-322. 